\title{
Association between XPD gene polymorphisms and esophageal squamous cell carcinoma
}

\author{
RUI-ZHONG LI ${ }^{1}$ and JIAN SUN ${ }^{2}$ \\ Departments of ${ }^{1}$ Oncology and ${ }^{2}$ Cardiothoracic Surgery, the First People's Hospital of Yancheng City, \\ Yancheng, Jiangsu 224005, P.R. China
}

Received August 24, 2012; Accepted November 14, 2012

DOI: $10.3892 / \mathrm{mmr} .2012 .1215$

\begin{abstract}
Single nucleotide polymorphisms (SNPs) of Xeroderma pigmentosum group $D(X P D)$ are associated with various types of cancer. However, previous studies of correlations between SNPs in this gene and esophageal squamous cell carcinoma (ESCC) have generated conflicting results. In the present study, we investigated the potential relationship between SNPs in two key regions of XPD, codons 312 and 751 and ESCC in a Chinese population. Polymerase chain reaction-restriction fragment length polymorphism was used to analyze genotypes at codons 312 and 751 of XPD in 400 ESCC patients (case group) and 400 healthy individuals (control group). Logistic regression was used to analyze the relationship between genotypes and ESCC. No statistically significant difference was observed for the genotype or allele frequencies of codon 312 between case and control groups ( $P>0.05)$. However, a statistically significant difference was observed in the genotype and allele frequencies of codon 751 between the case and control groups $(\mathrm{P}<0.05)$. Specifically, compared with the AA genotype at codon 751, a significant increase in risk of ESCC was detected for individuals with the $\mathrm{CC}$ genotype $(\mathrm{OR}=1.600 ; 95 \% \mathrm{CI}, 1.137-2.253$; $\mathrm{P}=0.007)$. Therefore, $X P D$ polymorphism at codon 312 is not correlated with ESCC, while polymorphism at codon 751 is associated with ESCC and the CC genotype may confer increased susceptibility to the disease.
\end{abstract}

\section{Introduction}

Esophageal cancer occurs frequently, with an incidence ranked 8 th among all tumor types. This form of cancer is associated with a high degree of malignancy and a poor 5-year survival

Correspondence to: Dr Jian Sun, Department of Cardiothoracic Surgery, the First People's Hospital of Yancheng City, 16 Yuehe Road, Yancheng, Jiangsu 224005, P.R. China

E-mail: jiansun0515@126.com

Key words: esophageal squamous cell carcinoma, Xeroderma pigmentosum group $D$, gene polymorphism rate of $<10 \%(1-2)$. The prevalence of esophageal cancer, in particular esophageal squamous cell carcinoma (ESCC), is extremely high in China, with $\sim 250,000$ new cases arise annually, accounting for $50 \%$ of all cases worldwide (3).

However, despite the frequent occurrence and high mortality of esophageal cancer, its pathogenesis remains unknown. Esophageal cancer is generally accepted to be a complex polygenic disease caused by genetic and environmental factors. Studies have demonstrated that defects in DNA damage repair lead to accumulated DNA damage, which confers a higher risk of cancer (4). The most important DNA damage repair mechanism in humans is nucleotide excision repair (NER) (5). NER is performed by a number of proteins, for deficiencies that cause human diseases, including Xeroderma pigmentosum and Cockayne syndrome. A key NER protein, Xeroderma pigmentosum group $D(X P D)$, a subunit of transcription factor IIH, has ATP-dependent $5^{\prime} \rightarrow 3^{\prime}$ helicase activity and is involved in gene transcription with the action of RNA polymerase II $(6,7)$. Additionally, XPD interacts with p53 to co-regulate cell apoptosis (8). Thus, XPD is essential to DNA repair capacity and complete XPD gene deletion results in embryonic death (9).

$X P D$, also known as excision repair cross-complementing, maps to a 5.4-kb region of human chromosome 9. Eight single nucleotide polymorphisms (SNPs) have been found in the coding region thus far and among these, variations in codons $312(\mathrm{G} \rightarrow \mathrm{A})$ and $751(\mathrm{~A} \rightarrow \mathrm{C})$ are the most common $(10)$. Numerous studies have investigated potential associations between XPD polymorphisms and various types of cancer, including head and neck squamous, lung squamous and basal cell carcinomas and breast and gastric cancers (11-15). However, a limited number of studies have explored the relationship between $X P D$ polymorphisms and ESCC and have yielded inconsistent results (16-19). Therefore, this case-control study assessed whether SNPs in codons 312 and 751 of XPD are associated with ESCC in a Chinese population.

\section{Materials and methods}

Study subjects. The present study was a population-based case-control study. Between January 2008 and December 2011, 400 patients with ESCC (case group) whose diagnoses were confirmed by pathological biopsy of tissues removed by endoscopic or surgical excision were recruited. Healthy individuals 
(control group) were confirmed by endoscopic census to be free of esophageal cancer and precancerous lesions over the same period in the same geographical area. Information on gender, age, smoking status and alcohol consumption of case and control group individuals was obtained. The 400 healthy individuals were gender- and age-matched with the case group. Smoking was defined as $\geq 1$ cigarette/day continuously for $>6$ months. Alcohol consumption was defined as at least once/ week continuously for $>6$ months. The study was approved by the First People's Hospital of Yancheng City Ethics Committee (Jiangsu, China) and all subjects provided written informed consent.

Specimen collection. Peripheral venous blood samples were obtained from all participants in a fasting state and stored at $-20^{\circ} \mathrm{C}$ for subsequent use.

Extraction of genomic DNA. Wizard genomic DNA extraction kits (Promega Corporation, Madison, WI, USA) were used to extract genomic DNA according to the manufacturer's instructions.

Concentration and purity of genomic DNA. ND-1000 UV/VIS spectrophotometer (Nanodrop Corporation, Wilmington, DE, USA) was used to perform quantitative determination of the DNA samples. Template DNA concentration was adjusted to 25-50 ng/ $\mu 1$.

Polymerase chain reaction (PCR). Genotypes at the 312 and 751 loci of $X P D$ were determined using PCR-restriction fragment length polymorphism (RFLP). Primers were synthesized by Sangon Biological Engineering Technology Co., Ltd. (Shanghai, China). For codon 312, the primer sequences used were: upstream, 5'-CTGTTGGTGGGTGCCCGTATCTGTT GGTCT-3'; downstream, 5'-TAATATCGGGGCTCACCCT GCAGCACTTCCT-3'. PCR mix $(20 \mu \mathrm{l})$ containing $100 \mathrm{ng}$ DNA template, $2.0 \mu 1$ 10X PCR buffer solution (with $15 \mathrm{mM}$ $\left.\mathrm{MgCl}_{2}\right), 0.4 \mu \mathrm{ldNTP}(10 \mathrm{mM}), 1.5 \mu \mathrm{l}$ each primer $(150 \mathrm{mM})$,

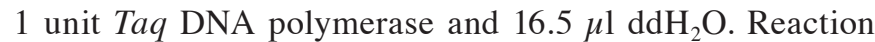
conditions were as follows: $94^{\circ} \mathrm{C}$ for $5 \mathrm{~min} ; 35$ cycles of $94^{\circ} \mathrm{C}$ for $45 \mathrm{sec}, 69^{\circ} \mathrm{C}$ for $45 \mathrm{sec}$ and $72^{\circ} \mathrm{C}$ for $45 \mathrm{sec}$; and $72^{\circ} \mathrm{C}$ for $7 \mathrm{~min}$. PCR products were digested using the StyI restriction enzyme (New England Biolabs, Ipswich, MA, USA) at $37^{\circ} \mathrm{C}$ for $16 \mathrm{~h}$. For codon 751, primer sequences used were: upstream, 5'-GCCCGCTCTGGATTATACG-3'; downstream, 5'-CTATC ATCTCCTGGCCCCC-3'. PCR mix $(20 \mu \mathrm{l})$ containing $100 \mathrm{ng}$ DNA template, $2.0 \mu 1$ 10X PCR buffer solution $\left(\mathrm{Mg}^{2+}\right.$-free), $1.2 \mu \mathrm{Mgg}^{2+}$ solution (25 mM MgCl 2$), 0.5 \mu \mathrm{ldNTS}(10 \mathrm{mM})$, $1.5 \mu \mathrm{l}$ each primer $(150 \mathrm{mM})$ and 25 units $\mathrm{Taq}$ DNA polymerase. Reaction conditions were as follows: $94^{\circ} \mathrm{C}$ for $5 \mathrm{~min}$; 35 cycles of $94^{\circ} \mathrm{C}$ for $45 \mathrm{sec}, 63^{\circ} \mathrm{C}$ for $45 \mathrm{sec}$ and $72^{\circ} \mathrm{C}$ for $45 \mathrm{sec}$; and $72^{\circ} \mathrm{C}$ for $7 \mathrm{~min}$. PCR products were digested using the Pst $\mathrm{I}$ restriction enzyme (New England Biolabs) at $37^{\circ} \mathrm{C}$ for $16 \mathrm{~h}$. Codon products were visualized on $2 \%$ agarose gels using a gel imaging system. Restriction fragments were sent to Beijing Genomics Institute (Beijing, China) for direct gene sequencing.

Statistical analysis. SPSS 17.0 statistical software was used for statistical analysis. The two-sample t-test was used to compare differences between the two groups and the $\chi^{2}$ test was used
Table I. Comparison of basic characteristics between ESCC cases and healthy controls.

\begin{tabular}{lcccc}
\hline Variable & $\begin{array}{c}\text { Controls } \\
(\mathrm{n}=400)\end{array}$ & $\begin{array}{c}\text { Cases } \\
(\mathrm{n}=400)\end{array}$ & $\mathrm{t} / \chi^{2 \mathrm{a}}$ & P-value \\
\hline $\begin{array}{l}\text { Age, years } \\
\text { (mean } \pm \text { SD) }\end{array}$ & $63.2 \pm 9.6$ & $62.9 \pm 9.5$ & 0.498 & 0.618 \\
Age, years (\%) & & & & \\
$<60$ & $137(34.3)$ & $150(37.5)$ & 0.918 & 0.338 \\
$\geq 60$ & $263(65.8)$ & $250(62.5)$ & & \\
Gender (\%) & & & & \\
Male & $272(68.0)$ & $257(64.3)$ & 1.256 & 0.262 \\
Female & $128(32.0)$ & $143(35.8)$ & & \\
Smoking status $(\%)$ & & & & \\
$\quad$ Non-smoking & $266(66.5)$ & $224(56.0)$ & & \\
Smoking & $134(33.5)$ & $176(44.0)$ & 9.290 & 0.002 \\
Alcohol consumer $(\%)$ & & & & \\
No & $296(74.0)$ & $263(65.8)$ & & \\
Yes & $104(26.0)$ & $137(34.3)$ & 6.467 & 0.011 \\
\hline
\end{tabular}

ESCC, esophageal squamous cell carcinoma. at value for Age, $\chi^{2}$ value for other variables.

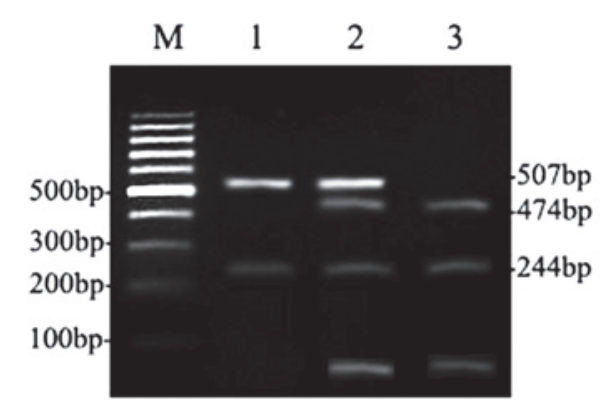

Figure 1. Electrophoretogram of three genotypes at $X P D$ codon 312. M, 100 bp DNA ladder. Lanes 1, GG; 2, GA and 3, AA genotypes. $X P D$, Xeroderma pigmentosum group D.

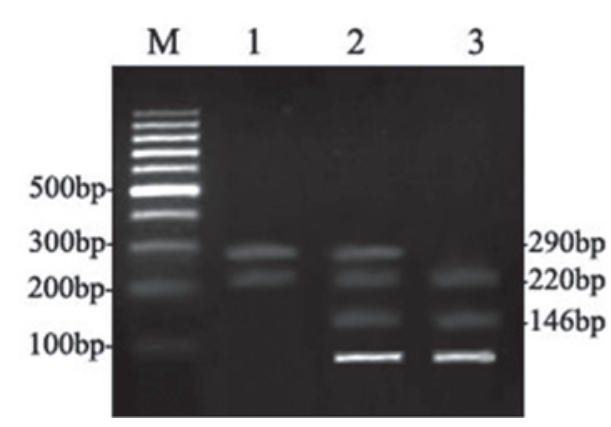

Figure 2. Electrophoretogram of three genotypes at $X P D$ codon 751 M, 100 bp DNA ladder. Lanes 1, AA; 2, AC and 3, CC genotypes. XPD, Xeroderma pigmentosum group $D$.

to compare age, gender, smoking status, alcohol consumption and genotype and allele frequencies between the two groups. The relationship between gene polymorphism and ESCC was 
A

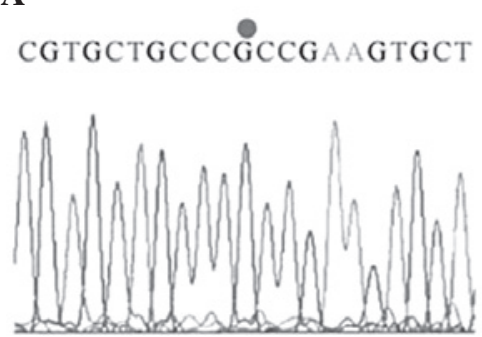

B

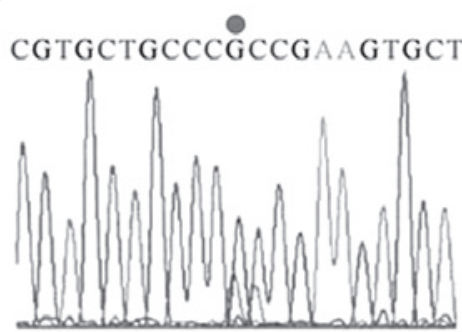

C

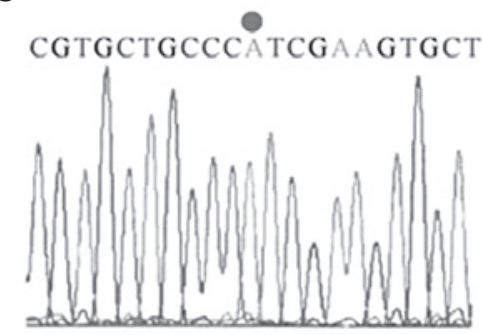

Figure 3. Sequencing graphs of restriction fragments for XPD codon 312. (A) GG, (B) GA, and (C) AA genotypes. XPD, Xeroderma pigmentosum group D.

A GGAGACGCTGAAGAGGATAGA

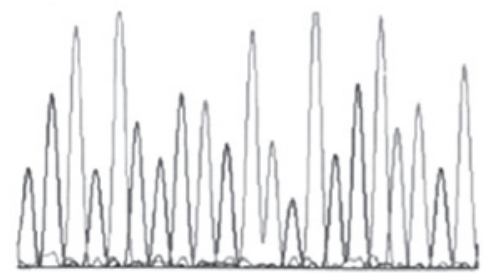

B GGAGACGCTGCAGAGGATAGA

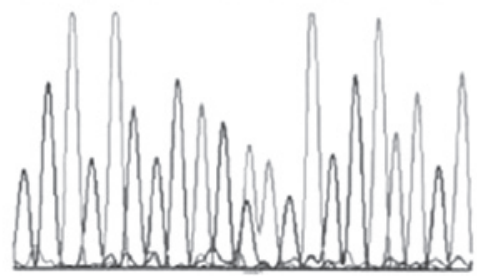

C GGAGACGCTGCAGAGGATAGA

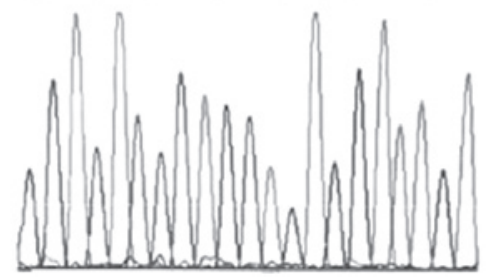

Figure 4. Sequencing graphs of restriction fragments for XPD codon 751. (A) AA, (B) AC, and (C) CC genotypes. XPD, Xeroderma pigmentosum group D.

analyzed using logistic regression to obtain odds ratios (OR) and $95 \%$ confidence intervals (CI). Analyses were performed with two-sided tests. $\mathrm{P}<0.05$ was considered to indicate a statistically significant difference.

\section{Results}

Population characteristics. Age, gender, smoking status and alcohol consumption of the 400 ESCC cases and 400 healthy controls included in this study are presented in Table I. Controls were age- and gender-matched to cases. Age ranges and gender distributions of the two groups were not identified as significantly different, although ESCC occurred twice as often in males. However, statistically significant increases in cigarette smoking and alcohol consumption were observed in the ESCC patients (44.0 and 34.3\%, respectively) compared with the controls ( 33.5 and $26 \%$, respectively; $\mathrm{P}<0.05$ ).

Comparison of genotype and allele frequencies for SNPs 312 and 751 between ESCC and healthy individuals. The expected PCR product size for the 312 locus was $751 \mathrm{bp}$. StyI restriction digestion generated various products based on the genotype: GG resulted in 2 fragments, 507 and 244 bp; GA resulted in 4 fragments, 507, 474, 244 and 33 bp; and AA resulted in 3 fragments, 474, 244 and 33 bp (Fig. 1). For the 751 locus, the expected PCR product size was $436 \mathrm{bp}$. PstI restriction digestion generated the following: 2 fragments for the AA genotype, 290 and $146 \mathrm{bp}$; 4 fragments for AC, 290, 227, 146 and 63 bp; and 3 fragments for CC, 227, 146 and 63 bp (Fig. 2). Sequencing of these restriction products was consistent with the expected sequence (Figs. 3 and 4).

The distributions of genotypes for $X P D$ codons 312 and 751 were consistent with Hardy-Weinberg equilibrium for cases and controls $(\mathrm{P}>0.05)$. No statistically significant differences in genotype or allele frequencies for codon 312 were observed between cases and controls (Table II). However, statistically significant differences in genotype and allele frequencies for codon 751 were observed between cases and controls $(\mathrm{P}<0.05$; Table III).

Relationship between genotype and ESCC. Results of the logistic regression analysis indicated that gender was a confounding factor for $\operatorname{ESCC}(\mathrm{P}=0.039)$, while age, smoking status and alcohol consumption had no correlation with the occurrence of ESCC $(\mathrm{P}>0.05)$. Excluding the effect of gender resulted in no correlation between SNP in codon 312 and occurrence of ESCC $(\mathrm{P}>0.05)$. However, a correlation was observed between codon 751 genotype and ESCC occurrence. No significant increase in ESCC risk was observed for cases with the AC genotype compared with those with the AA genotype $(\mathrm{P}=0.137)$. ESCC risk in cases with the $\mathrm{CC}$ genotype was increased by 1.6-fold (OR, 1.600; 95\% CI; 1.137-2.253; $\mathrm{P}=0.007$; Table IV).

\section{Discussion}

Previous studies on the association between $X P D$ polymorphisms and ESCC are controversial. However, the present study provides additional confirmation of a correlation between a SNP in $X P D$, specifically within codon 751 and ESCC. No significant correlation was observed between the SNP in codon 312 and occurrence of ESCC, consistent with results of previous studies on the relationship between polymorphisms of XPD codon 312 and risk of esophageal cancer. Specifically, Zhou et al (17) and Wu et al (19) reported no correlation between polymorphisms at this locus and occurrence of ESCC in Chinese populations. Similarly, Tse et al (20) found no such correlation in a predominantly Caucasian population. By contrast, we report that a polymorphism in codon 751 of $X P D$ is significantly correlated with occurrence of ESCC and 
Table II. Comparison of genotype and allele frequencies for XPD codon 312 between groups, no. (\%).

\begin{tabular}{|c|c|c|c|c|c|c|}
\hline \multirow[b]{2}{*}{ Group } & \multirow[b]{2}{*}{ No. } & \multicolumn{3}{|c|}{ Genotype } & \multicolumn{2}{|c|}{ Allele } \\
\hline & & GG & GA & AA & G & A \\
\hline Controls & 400 & 351 (87.8) & 47 (11.8) & $2(0.5)$ & 749 (93.6) & $51(6.4)$ \\
\hline Cases & 400 & $342(85.5)$ & $56(14.0)$ & $2(0.5)$ & $740(92.5)$ & $60(7.5)$ \\
\hline$\chi^{2}$ & & & 0.903 & & 0.784 & 0.784 \\
\hline P-value & & & 0.637 & & 0.376 & 0.376 \\
\hline
\end{tabular}

XPD, Xeroderma pigmentosum group D.

Table III. Comparison of genotype and allele frequencies for XPD codon 751 between groups, no. (\%).

\begin{tabular}{|c|c|c|c|c|c|c|}
\hline \multirow[b]{2}{*}{ Group } & \multirow[b]{2}{*}{ No. } & \multicolumn{3}{|c|}{ Genotype } & \multicolumn{2}{|c|}{ Allele } \\
\hline & & AA & $\mathrm{AC}$ & $\mathrm{CC}$ & A & $\mathrm{C}$ \\
\hline Controls & 400 & $321(80.3)$ & $73(18.3)$ & $6(1.5)$ & 715 (89.4) & $85(10.6)$ \\
\hline Cases & 400 & $283(70.8)$ & 105 (26.3) & $12(3.0)$ & $671(83.9)$ & $129(16.1)$ \\
\hline$\chi^{2}$ & & & 10.144 & & 10.444 & 10.444 \\
\hline P-value & & & 0.006 & & 0.001 & 0.001 \\
\hline
\end{tabular}

XPD, Xeroderma pigmentosum group D.

Table IV. Association between XPD polymorphism and ESCC.

\begin{tabular}{|c|c|c|c|c|}
\hline Variable & $\begin{array}{l}\text { Controls } \\
(n=400)\end{array}$ & $\begin{array}{c}\text { Cases } \\
(n=400)\end{array}$ & OR $(95 \% \mathrm{CI})$ & P-value \\
\hline \multicolumn{5}{|l|}{ Age } \\
\hline$<60$ & $137(34.3)$ & $150(37.5)$ & Reference & \\
\hline$\geq 60$ & $263(65.8)$ & $250(62.5)$ & $0.866(0.644-1.164)$ & 0.341 \\
\hline \multicolumn{5}{|l|}{ Gender } \\
\hline Male & $272(68.0)$ & $257(64.3)$ & Reference & 0.039 \\
\hline Female & $128(32.0)$ & $143(35.8)$ & $1.391(1.016-1.905)$ & \\
\hline \multicolumn{5}{|l|}{ Smoking status } \\
\hline Non-smoking & $266(66.5)$ & $224(56.0)$ & Reference & \\
\hline Smoking & $134(33.5)$ & $176(44.0)$ & $1.507(0.985-2.305)$ & 0.059 \\
\hline \multicolumn{5}{|l|}{ Alcohol consumer } \\
\hline Never consume alcohol & $296(74.0)$ & $263(65.8)$ & Reference & \\
\hline Consume alcohol & $104(26.0)$ & $137(34.3)$ & $1.177(0.748-1.850)$ & 0.481 \\
\hline \multicolumn{5}{|l|}{ Codon } \\
\hline $312 \mathrm{GG}$ & $351(87.8)$ & $342(85.5)$ & Reference & \\
\hline 312 GA & $47(11.8)$ & $56(14.0)$ & $1.166(0.762-1.783)$ & 0.480 \\
\hline $312 \mathrm{AA}$ & $2(0.5)$ & $2(0.5)$ & $1.013(0.138-7.441)$ & 0.990 \\
\hline $751 \mathrm{AA}$ & $321(80.3)$ & $283(70.8)$ & Reference & \\
\hline $751 \mathrm{AC}$ & $73(18.3)$ & $105(26.3)$ & $2.149(0.785-5.884)$ & 0.137 \\
\hline $751 \mathrm{CC}$ & $6(1.5)$ & $12(3.0)$ & $1.600(1.137-2.253)$ & 0.007 \\
\hline
\end{tabular}

ESCC, esophageal squamous cell carcinoma. OR, odds ratio; CI, confidence interval. 
that individuals with the $\mathrm{CC}$ genotype (vs. AA) have a 1.6-fold higher risk of ESCC. Thus, the CC genotype confers increased susceptibility to ESCC, consistent with specific previous studies. In particular, researchers in the Taiwan Province of China reported that the $X P D$ codon 751 SNP is correlated with risk of esophageal cancer (21); Ye et al (16) found a similar correlation in a Swedish population. However, an earlier study in northern China identified no correlation between $X P D$ gene polymorphisms and ESCC (19), indicating that XPD polymorphisms may have different effects on genetic susceptibility to ESCC in various populations. A previous study indicated that, compared with the AA genotype, $\mathrm{CC}$ individuals have significantly reduced repair capacity of chromatid-type DNA aberrations (22). The structure of codon 751 is highly evolutionarily conserved, indicating a role in maintaining function of XPD. Therefore, mutation at this locus may affect the repair ability of XPD, as well as affecting its transcriptional activity and role in apoptosis, thereby promoting tumorigenesis.

In short, $X P D$ codon 751 polymorphism is markedly associated with ESCC susceptibility and the CC genotype may be a risk factor for ESCC. Therefore, detection of XPD polymorphism at this locus may aid in prevention and early diagnosis of ESCC. Corresponding functional studies are required to reveal molecular mechanisms that promote ESCC in individuals carrying $X P D$ variants.

\section{References}

1. Lambert R and Hainaut P: The multidisciplinary management of gastrointestinal cancer. Epidemiology of oesophagogastric cancer. Best Pract Res Clin Gastroenterol 21: 921-945, 2007.

2. Holmes RS and Vaughan TL: Epidemiology and pathogenesis of esophageal cancer. Semin Radiat Oncol 17: 2-9, 2007.

3. Lu S: Research progress on etiology of esophageal cancer. A specially invited set of reports for Annual Meeting Seminar of the Tenth China Association for Science and Technology. 129-132, 2008.

4. Matullo G, Palli D, Peluso M, et al: XRCC1, XRCC3, XPD gene polymorphisms, smoking and 32P-DNA adducts in a sample of healthy subjects. Carcinogenesis 22: 1437-1445, 2001.

5. Ishikawa T, Zhang SS, Qin X, Takahashi Y, Oda H, Nakatsuru Y and Ide F: DNA repair and cancer: lessons from mutant mouse modle. Cancer Sci 95: 112-117, 2004.

6. Egly JM: The 14th Datta Lecture. TFIIH: from transcription to clinic. FEBS Lett 498: 124-128, 2001.

7. Lehmann AR: The xeroderma pigmentosum group D (XPD) gene: one gene, two functions, three diseases. Genes Dev 15 $15-23,2001$

8. Wang XW, Vermeulen W, Coursen JD, et al: The XPB and XPD DNA helicases are components of the p53-mediated apoptosis pathway. Genes Dev 10: 1219-1232, 1996.
9. de Boer J, Donker I, de Wit J, Hoeijmakers JH and Weeda G: Disruption of the mouse xeroderma pigmentosum group $D$ DNA repair/basal transcription gene results in preimplantation lethality. Cancer Res 58: 89-94, 1998.

10. Manuguerra M, Saletta F, Karagas MR, Berwick M, Veglia F, Vineis P and Matullo G: XRCC3 and XPD/ERCC2 single nucleotide polymorphisms and the risk of cancer: a HuGe review. Am J Epidemiol 164: 297-302, 2006.

11. Sturgis EM, Zheng R, Li L, Castillo EJ, Eicher SA, Chen M, Strom SS, Spitz MR and Wei Q: XPD/ERCC2 polymorphism and risk of head and neck cancer: a case-control analysis. Carcinogenesis 21: 2219-2223, 2000.

12. Butkiewicz D, Rusin M, Enewold L, Shields PG, Chorazy M and Harris CC: Genetic polymorphisms in DNA repairs genes and risk of lung cancer. Carcinogenesis 22: 593-597, 2001.

13. Dybdahl M, Vogel U, Frentz G, Wallin H and Nexø BA: Polymorphisms in the DNA repair gene XPD: correlations with risk and age at onset of basal cell carcinoma. Cancer Epidemiol Biomarkers Prev 8: 77-81, 1999.

14. Tang D, Cho S, Rundle A, Chen S, Phillips D, Zhou J, Hsu Y, Schnabel F, Estabrook A and Perera FP: Polymorphisms in the DNA repair enzyme XPD are associated with increased levels of PAH-DNA adducts in a case-control study of breast cancer. Breast Cancer Res Treat 75: 159-166, 2002.

15. Ruzzo A, Canestrari E, Maltese P, et al: Polymorphisms in genes involved in DNA repair and metabolism of xenobiotics in individual susceptibility to sporadic diffuse gastric cancer. Clin Chem Lab Med 45: 822-828, 2007.

16. Ye W, Kumar R, Bacova G, Lagergren J, Hemminki K and Nyrén O: The XPD 751Gln allele is associated with an increased risk for esophageal adenocarcinoma: a population-based case-control study in Sweden. Carcinogenesis 27: 1835-1841, 2006.

17. Zhou R, Li Y, Wang N, et al: Association study on mononucleotide polymorphism of XPD gene and risk of esophageal squamous cell carcinoma, gastric cardiac adenocarcinoma. Tumor 27: 118-123, 2007.

18. Chen M, Wang J and Guo G: The correlation of repair gene XPD Lys751Gln for DNA damage, XRCC1 Arg399Gln polymorphism mononucleotide with genetic susceptibility of esophageal cancer. Fudan University (Med Sci) 35: 273-278, 2008.

19. Wu X, Wang P, Yun Y, et al: The relationship between esophageal squamous cell carcinoma in Henan Han Chinese and XPD gene polymorphism. Public Health of China 28: 446-449, 2012 (In Chinese).

20. Tse D, Zhai R, Zhou W, Heist RS, Asomaning K, Su L, Lynch TJ, Wain JC, Christiani DC and Liu G: Polymorphisms of the NER pathway genes, ERCCI and XPD are associated with esophageal adenocarcinoma risk. Cancer Causes Control 19: 1077-1083, 2008.

21. Lee JM, Lee YC, Yang SY, Yang PW, Luh SP, Lee CJ, Chen CJ and Wu MT: Genetic polymorphisms of XRCC1 and risk of the esophageal cancer. Int J Cancer 95: 240-246, 2001.

22. Lunn RM, Helzlsouer KJ, Parshad R, Umbach DM, Harris EL, Sanford KK and Bell DA: XPD polymorphisms: effects on DNA repair proficiency. Carcinogenesis 21: 551-555, 2000. 